\title{
Dehydrogenase activity in topsoil at windthrow plots in Tatra National Park
}

\author{
Peter Hanajík ${ }^{1 *}$, Jana Gáfriková ${ }^{1}$, Milan Zvarík ${ }^{2}$ \\ ${ }^{1}$ Comenius University, Faculty of Natural Sciences, Mlynská dolina, Ilkovičova 6, SK - 84215 Bratislava 4, Slovak Republic \\ ${ }^{2}$ Comenius University, Faculty of Mathematics, Physics and Informatics, Mlynská dolina F1, SK-84248 Bratislava, Slovak Republic
}

\section{Abstract}

The aim of the study was to compare the effect of windthrow treatments established after the windstorm in 2004 on the activity of enzyme dehydrogenase (DHA) in forest topsoils. We also focused on the effect of the recent windthrow (May 2014) on the DHA in topsoil. Soil samples were collected in July 2014 from four sites in the Tatra National Park: EXT - tree trunks and wood debris extracted after the windstorm in 2004, NEX - area left for self-regeneration after the windstorm in 2004, REX - tree trunks and wood debris extracted after the windstorm (May 2014), REN - Norway spruce stand set as a control plot. We measured $\mathrm{pH}$, dry weight \%, soil organic matter (SOM), carbon content in microbial biomass $\left(\mathrm{C}_{\text {bio }}\right)$ and DHA. Dehydrogenase activity at studied plots was the lowest at the EXT plot and the highest values were measured at the REN plot. DHA at NEX was similar to REN suggesting comparable ecological conditions at these plots comparing to EXT. Carbon content in microbial biomass at plots reflected intensity of dehydrogenase activity in sequence $\mathrm{EXT}<\mathrm{REX}<\mathrm{NEX}<\mathrm{REN}$.
\end{abstract}

Key words: topsoil; dehydrogenase activity; soil organic matter; windthrow; Tatra National Park

Editor: Erika Gömöryová

\section{Introduction}

Soil is very heterogeneous ecosystem, where thousands of living species provide number of functions. Avast density and diversity of microorganisms can be detached even in a small soil compartment (Dilly 2010). Physiological functioning and corresponding biochemical reactions of living organisms are mainly controlled by enzymatic reactions catalyzed by specific enzyme or a group of enzymes. Soil enzymes are necessary for maintaining soil ecology, physical and chemical properties or soil health (Paul 2007). Enzymatic activities are closely linked with microbial activity or biomass, thus they can generally serve as indicators of shifts in soil properties (Das \& Varma 2011). At ecosystem level, linkage among enzyme activity and the transformation of carbon and nitrogen can indicate a different management approaches (Salazar et al. 2011). DHA is commonly used as an indicator of biological activity in soils. Dehydrogenase is intercellular enzyme that does not accumulate in soil but is an integral part of intact vital cell participating in the respiration metabolic pathways. Main function of dehydrogenase is to transfer protons and electrons from substrates to acceptors, the processes involved in the oxidation of SOM. Many factors, such as soil moisture, redox potential, organic mat- ter content, $\mathrm{pH}$, temperature, seasonal variations etc. can influence soil characteristics and thus enzymatic activities (Wolinska \& Stepniewska 2012). Seasonal changes of dehydrogenase activity were reported in forest soil during wet and dry periods of the year.

Windstorms create gaps in forest canopy effecting soil nutrient availability and enzyme activity. Size of the gap is an important parameter influencing soil characteristics. The large size gaps cause decrease of soil organic matter, nitrogen and phosphorus, enzyme activity and increase the nutrients loss (Xu et al. 2016; Yang et al. 2017). Salvage logging at windthrow sites can result in reduction and more uniform distribution of post-windthrow structural atributes that can cause significant differences between natural disturbances and managed forests (Waldron et al. 2013). Removal of logging residues can have significant effect also on soil processes and enzyme activities. Increase of enzymatic activity on the sites with no removal of logging residues indicates importance of these materials in sustainable productivity of forest ecosystems (Adamczyk et al. 2015). Soil biological activity and decomposition/mineralization of soil organic matter are essential in forest functioning as they make nutrients more available to the vegetation. Relatively to stem -only harvest, microbial activity, enzymatic activities 
and $\mathrm{N}$ mineralization fluxes are reduced in intensive harvests. Enzymatic activities involved in $\mathrm{N}$ mineralization, C decomposition or phosphate hydrolyze are decreased as well (Achat et al.2015). Studies also showed that forest thinning and soil disturbance can decrease protease and arylsulfatase activity but may not have affect glucosaminase, glucosidase and acid phosphatase activities. Cellulase, phenoloxidase, arylsulfatase and protease correlate after thinning with active $C$ and peroxidase activity is negatively correlated to active $C$. Peroxidase, phenol oxidase, arysulfatase and protease activities correlate with soil microbial nitrogen (Geng et al. 2012).

Among all soil microorganisms, bacteria and microscopic fungi are the most important groups involved in soil biochemically mediated processes. They play irreplaceable roles in nutrient cycling or organic matter dynamics (Pett-Ridge \& Firestone 2005). Microorganisms significantly contribute to chemical alteration of organic residues via the enzymes production thus affect organic carbon cycling as well (Bardgett 2005). Dehydrogenase is strongly linked to $\mathrm{C}$-cycling in different forest ecosystems and thus its activity can be correlated with organic carbon content (Salazar et al. 2011) and microbial biomass (Fontaine et al. 2003).

This study focused on the comparison of DHA in topsoils at the plots with different windthrow treatment. Longtime effect of shifted ecological conditions and secondary succession have impact on soil parameters reflecting also in microbial community structure and thus in enzymatic activities as well. Our hypothesis in this study was that DHA at REN and NEX would differ from EXT and REX site.

Ecological conditions at NEX and REN plots have similar effect on topsoil characteristics in contrast to EXT plot where the effect of ecological factors on soil resemble condition of recently damaged plot REX. Shifts in microbial community structure reflect intensity of ecological factors in soils. We can assume that the similar microbial structure identified at studied plots showed also similarity in ecological factors. Microbial community structure on the NEX plot is more similar to reference plot over time while EXT showed significant differences (Hanajík 2015; Hanajík \& Fritze 2009). DHAwas assumed to be the highest at plot EXT due to herbaceous vegetation cover and its thicker root system which would enhance microbial processes thus also DHA activity. We also expected DHA at plots to be linked with the measured carbon content in microbial biomass.

\section{Material and methods}

Thestudyplotswerelocatedatwindthrowareain TANAPin northern Slovakia. Predamaged forest was mostly (72.4\%) a 79-year-old Norway spruce (Picea abies L.) stand (Koreň 2005). Mineral topsoil 0 - $10 \mathrm{~cm}$ was sampled in July 2014 from four different treatments represented by plots $30 \times$ 30 m. Plot EXT (N 4907'12.0” E 02009'47.5”) repre- sented area with removal of fallen tree trunks and wood debris (over 8000 ha) after the windstorm in November 2004 covered mainly by herbaceous vegetation; Plot NEX (N 4909'60.5" E $020^{\circ} 15^{\prime} 14.8^{\prime \prime}$ ) was set in the area left for self-regeneration (over 690 ha) with domination of $R u b u$ s idaeus and plot REN (N 4907'19.5" E 02006'21.4") was situated in the Norway spruce stand as a control, plot was rich in mosses. Plot REX (N 4907'17.5” E 02006'16.4”) represented former reference (REF) area of spruce stand damaged by another windstorm in 2014 with following tree trunks and wood debris removal at this site, plot was covered mainly by herbaceous vegetation. For more detail description of vegetation cover on studied plots see Hanajík et al. (2016). The soil type at study plots was Cambic podzol. From each plot 45 individual core samples of topsoil were combined into 3 composite samples. One composite sample included 15 individual core samples. After the plant material was removed, the 12 composite samples were then sieved through a $2.0 \mathrm{~mm}$ mesh and stored at $4{ }^{\circ} \mathrm{C}$ until analyzed.

To determine dry weight percentage (DW \%) of soil, samples were dried at $105^{\circ} \mathrm{C}$ overnight. SOM content was measured as a loss on ignition from the dried samples at $550^{\circ} \mathrm{C}$ for $4 \mathrm{~h}$. Soil $\mathrm{pH}$ was measured by a glass electrode in soil suspension with deionized water $\mathrm{pH} / \mathrm{H}_{2} \mathrm{O}$ and $\mathrm{KCL}$ $0.1 \mathrm{M} \mathrm{pH} / \mathrm{KCl}$.

Carbon content in microbial biomass $\left(\mathrm{C}_{\text {bio }}\right)$ was determined by chloroform fumigation extraction (CFE) method according to Vance et al. (1987) using membrane air pump N810.3FT.18 with automatic vacuum controller. For the CFE method, four subsamples of composite samples were fumigated with ethanol-free chloroform in a sealed desiccator in the dark for $24 \mathrm{~h}$ at 180 mbar pressure and then extracted using $0.5 \mathrm{M} \mathrm{K}_{2} \mathrm{SO}_{4}$. Non fumigated controls was extracted under the same conditions at the time fumigation commenced. Organic $\mathrm{C}_{\text {bio }}$ was then determined in extracts by dichromate digestion.

Quantification of dehydrogenase activity was based on the recommended standard assay. Method was originally described by Benefield \& Howard (1977), and adapted from Trevors (1984a, 1984b) and Von Mersi \& Schinner (1991). The principle of the method relies on the ability of iodonitrotetrazolium chloride (INT) to act as an artificial electron acceptor in the place of oxygen. Heterocyclic ring structure of INT readily accepts hydrogen atoms and electrons thus becomes reduced. During incubation INT is biologically reduced and forms purple water-insoluble iodonitrotetrazolium formazan (INTF) which can be extracted using organic solvent and amount is determined colorimetrically.

Data were compiled and transformed in Microsoft Excel. Statistics were generated using R software ver. 3.3.2. If the test statistic probability was less than the significance level $(\alpha=0.05)$, the null hypothesis for all tests was rejected. We tested collected data for normality by Shapiro-Wilk test followed by ANOVA and Tukey post hoc test for data from a normal distribution or Kruskal- 
Wallis and Kruskal-Wallis multiple comparison test for non-normally distributed data.

\section{Results and discussion}

Since, chemical reactions catalyzed by dehydrogenase, are associated with protons and electrons transfer $\mathrm{pH}$ of soil solution can influence its activity by changing either the ionic form of the active site of enzyme, affinity of substrate to enzyme or its three-dimensional shape (Wolinska \& Stepniewska 2012). This can be reflected in solubility and ionization of both organic and inorganic molecules present in soil solution. Interpretation of the $\mathrm{pH}$ effect on microbial processes can be difficult. Processes can be affected due to the cation sorbation at negatively charged surfaces of soil colloids $10-100$ times higher than the sorbation in soil solution. Hence, $\mathrm{pH}$ values of the colloid surface are generally lower comparing to the values measured in the soil solution. For example, the urease activity in soil, with optimum $\mathrm{pH}$ range between 8.5 and 9.0, is $1-2 \mathrm{pH}$ units higher than pH measured in the soil solution (Hazlett et al. 2007). In general, the optimal $\mathrm{pH}$ range for the activity of the enzymes related to the redox reactions is $7.4-8.5$, in comparison to soil solution, with its $\mathrm{pH}$ values $7-7.5$. However, a very poor activity was determined below $\mathrm{pH}$ 6.6 or above 9.5 (Januszek et al. 2015; Shaw \& Burns 2006). Dehydrogenase activity strong suppression can be observed at $\mathrm{pH}(\mathrm{KCl}) 4.1$ and $\mathrm{pH}\left(\mathrm{H}_{2} \mathrm{O}\right) 4.9$ (FernándezCalviño et al. 2010; Trevors 1984a). Different types of assays used in evaluation of the DHA in forest soils proved tight correlation between $\mathrm{pH}$ and dehydrogenase activity in Gleyic Podzols and Calcaric Cambisols (Januszek et al. 2015). Higher values of dehydrogenase were measured in sandy soils with neutral or slightly alkaline $\mathrm{pH}$. Positive correlation of dehydrogenase activity was also identified according to clay content and tree species composition (Blońska 2010; Fernández-Calviño et al. 2010). The use of buffer system when analyzing acidic or alcalic soils is recommended to obtain readable results. Comparing to acetate buffer, borate buffer, citrate buffer, and phosphate buffer which generally reduce DHA, TRIS buffer (1 M; pH 7.0) proved to be suitable for reproducibility and for measuring potential DHA (Von Mersi \& Schinner 1991). Soil reaction $\mathrm{pH}\left(\mathrm{H}_{2} \mathrm{O}\right)$ at studied plots ranged from 3.8 (NEX) to 4.5 (EXT) and $\mathrm{pH}(\mathrm{KCl})$ was 3.2 at EXT, REX and REN and 3.3 at NEX (Table 1).

Table 1. Soil reaction $\mathrm{pH}\left(\mathrm{H}_{2} \mathrm{O}\right)$ and $\mathrm{pH}(\mathrm{KCl})$ at studied plots $(\mathrm{n}=1)$.

\begin{tabular}{lcc}
\hline & $\mathrm{pH}\left(\mathrm{H}_{2} \mathrm{O}\right)$ & $\mathrm{pH}(\mathrm{KCl})$ \\
\hline EXT & 4.5 & 3.2 \\
NEX & 3.8 & 3.3 \\
REX & 4.4 & 3.2 \\
REN & 4.0 & 3.2 \\
\hline
\end{tabular}

Soil reaction $\mathrm{pH}\left(\mathrm{H}_{2} \mathrm{O}\right)$ and $\mathrm{pH}(\mathrm{KCl})$ at studied plots were strongly acidic and very strongly acidic, respecti- vely. Differences among $\mathrm{pH}$ values can be caused by differences in soil structure affecting bounding of $\mathrm{H}^{+}$cations in soil matrix (Hazlett et al. 2007). This difference in soil structure could be the result of evolution of the vegetation cover and rizosphere at studied plots especially at the EXT and REX where herbaceous vegetation dominated (Hanajík et al. 2016). Root systems and exudates of the vegetation at these plots affected very likely the soil nutrition properties (Chen et al. 2016) and thus were reflected in higher $\mathrm{pH}\left(\mathrm{H}_{2} \mathrm{O}\right)$ values comparing to $\mathrm{REN}$ and NEX plots with lower abundance of herbaceous species. However, to our knowledge no research was so far focused on soil structure differences among windthrow plots in the High Tatras proving or disproving significant effect of soil structure or vegetation cover on the soil reaction.

Dry weight percentage can reflect relative content of water in samples thus samples with high DW \% represented plots with low moisture content and low dry weight indicated high moisture content at the plots. Water content in soil is very important factor affecting microbial communities and their biomass thus have strong effect on DHA as well (Wolinska \& Stepniewska 2012). Dry weight values were the lowest at the NEX plot and the highest values were measured at the EXT plot. The lowest dry weight was detected at NEX plot and the highest at EXT (Fig. 1a). Kruskal-Wallis multiple comparison test then revealed statistical significant difference of plot EXT from all other plots $(\mathrm{p}<0.001)$. We recorded the lowest content of water in soil at EXT comparing to NEX, REX and REN where moisture conditions were similar. Since, dehydrogenase activity is strongly dependent also on soil aeration, thus its low values can be measured in soil with high water potential and anoxic conditions (Quilchano \& Marañón 2002; Song et al. 2008). Nevertheless we measured low DHA at the EXT site despite the low water content in soil. This could be explained by the complex infuence of other ecological factors. Low DHA at REX plot could be caused by recent disturbance of soil system that affected biodiversity of microbiocenosis at this plot and thus werereflected in the lower DHA in spite of of similar $\mathrm{C}_{\text {bio }}$ content comparing to NEX and REN. Lower water content at EXT plot is probably the result ofthick herbaceous layer at this site that wasformed after removal of damaged tree trunks. Herbaceous community demands higher water supply and causes higher levels of evapotranspiration as well draining water content from soils (Özkan \& Gökbulak 2017).

Content of SOM in dried samples was the lowest at the REX plot an the highest values were detected at the REN plot (Fig. 1b). Also data of SOM were not from the normally distributed population due to the Shapiro-Wilk test and thus were tested by Kruskal-Wallis test, showing statistical significancy. Kruskal-Wallis multiple comparison test revealed statistical significant difference of plot REN from all other plots ( $\mathrm{p}<0.001)$.SOM content provides organic compounds in soils important for metabolic activities of microorganisms which enhance decom 

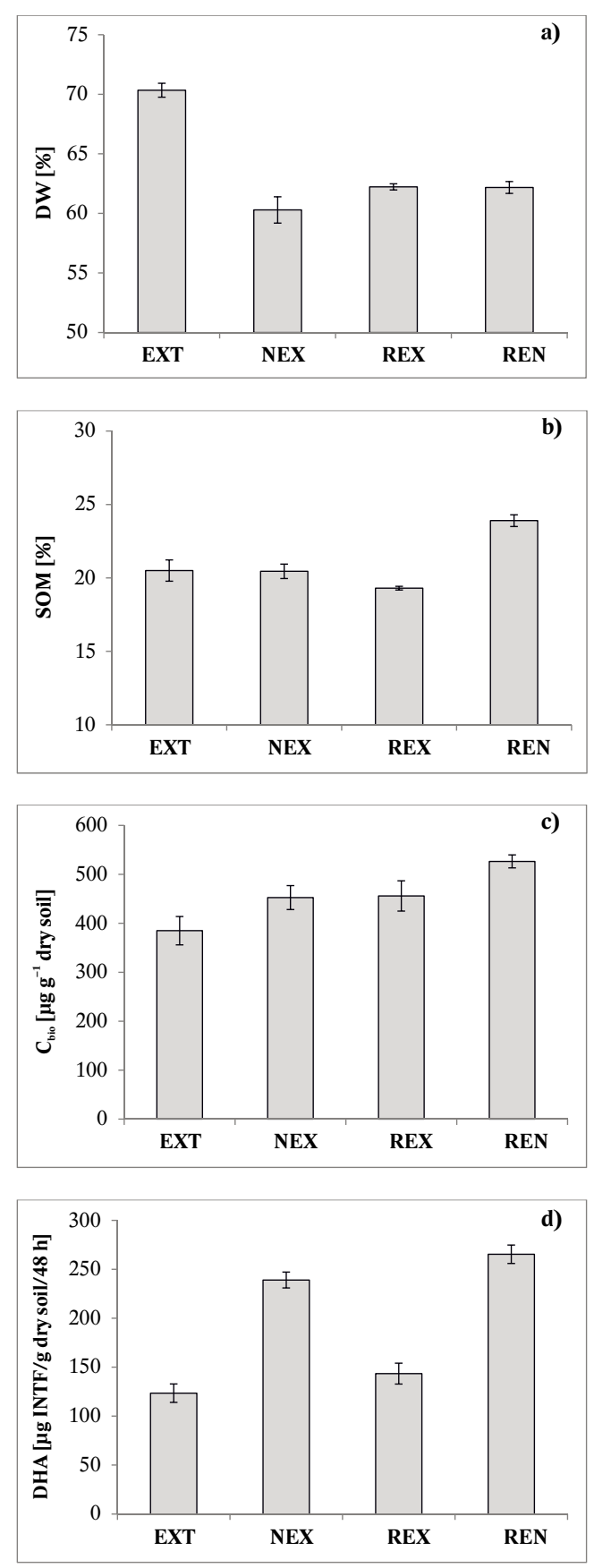

Fig. 1. DW\% a), SOM\% b), $C_{\text {bio }}$ c), DHA d), at studied plots. Values expressed as means with standard error $(n=12$ for each site).

position processes and nutrient cycles (Adamczyk et al. 2016). Organic matter content at our studied plots was the highest at REN plot wherewhere the highest DHA was detected. This could be considered as a confirmation of SOM importance as a factor effecting DHA; however, similar content of SOM at EXT, NEX and REXcontrasted with high variation of DHA values at these plots thus contradicted possible main effect of SOM on DHA under field conditions at the studied plots.

Carbon content in microbial biomass $\mathrm{C}_{\text {bio }}$ was the lowest at the EXT plot and the highest values were measured at the REN plot Data were from the normally distributed population due to the Shapiro-Wilk test and thus were tested by ANOVA, showing statistical significancy $(p=0.0052)$. Tukey test revealed statistical significancy between EXT and REN plot $(p=0.0023)$. Carbon content in microbial biomass tended to increase with increasingDHA at studied plots in sequence: EXT $<$ $\mathrm{REX}<\mathrm{NEX}<\mathrm{REN}$. This findings proved the main influence of microbial biomass in soil on DHA at studied plots. This is however well known fact that microbial biomass generally increases DHA in soils.

Dehydrogenase activity was the lowest at the EXT plot and the highest values were detected at the REN plot (Fig. 1d). Data of DHA were from the normally distributed population due to the Shapiro-Wilk thus tested by ANOVA, showing statistical significancy $(p<0.0001)$. Tukey test revealed statistical significancy among EXT and REN, REX and REN, EXT and NEX, NEX and REX (Table 2).

Table 2. Statistical evaluation of studied parameter.

\begin{tabular}{lcccc}
\hline & \multicolumn{4}{c}{ Parameters } \\
\hline Plots & $\mathrm{DW}^{*}$ & $\mathrm{SOM}^{*}$ & $\mathrm{C}_{\text {bio }}{ }^{*}$ & $\mathrm{DHA}^{* *}$ \\
EXT vs. REN & $<0.001$ & $<0.001$ & 0.0023 & $<0.001$ \\
REXvs. REN & 0.6781 & $<0.001$ & 0.1723 & $<0.001$ \\
EXTvs. NEX & $<0.001$ & 0.9864 & 0.2028 & $<0.001$ \\
NEX vs. REX & 0.0856 & 0.145 & 0.2715 & $<0.001$ \\
NEX vs. REN & 0.1868 & $<0.001$ & 0.3128 & 0.2215 \\
EXT vs. REX & $<0.001$ & 0.1586 & 0.9997 & 0.2502 \\
\hline
\end{tabular}

* -ANOVA (Tukey's test); * * Kruskal-Wallis (multiple comparison test).

DHA values positively correlated with $\mathrm{C}_{\mathrm{bio}}$ (correlation coefficient $0.61 ; p=0.035$ ) (Fig. 2). Statistical evaluation of studied parameters is shown in Table 2. DW and SOM were not correlating significantly with DHA however we identified negative trend between DHA and DW $(c=-0.57, p=0.055)$ and positive trend between DHA and SOM $(c=0.51, p=0.093)$.

\section{Conclusion}

DHA at the plots NEX and REN showed similar values comparing to EXT and REX. We assume that after 10 years of the vegetation succession at self-regeneration plot soil condition at this plot resemble more reference spruce stand comparing to the extracted plot where herbaceous layer dominated. The lowest DHA was recorded at EXT although we expected DHA to be enhanced by root exudates of herbal vegetationat this plot. We assume that this was caused by soil moisture deficiency as well as low $\mathrm{C}_{\text {bio }}$ content at this plot. Low intensity of DHA at REX plot was probably due to the recent disturbance at this plot destabilizing structure of microbiocenosis resulting in low DHA. Carbon content in microbial biomass at studied plots reflected intensity of dehydrogenase activity in sequence $\mathrm{EXT}<\mathrm{REX}<\mathrm{NEX}<\mathrm{REN}$ showing direct linkage between microbial biomass and DHA amounts. 


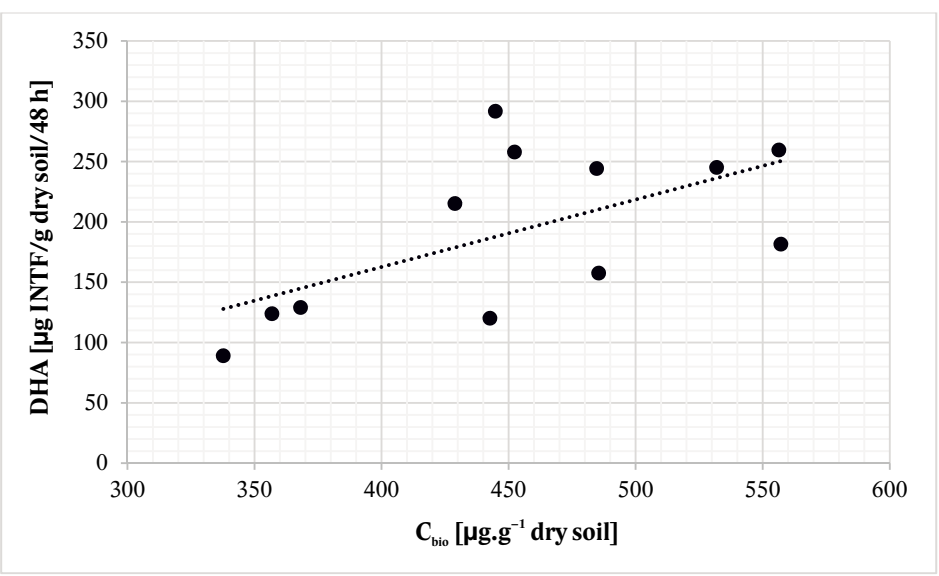

Fig. 2. Correlation between DHA and $C_{\text {bio }}(r=0,61 ; p=0,035)$.

\section{Acknowledgement}

The study was supported by the Ministry of Education, Science, Research and Sport of the Slovak Republic - project VEGA 1/0614/17 and by the Slovak Research and Development Agency - project APVV-0866-12.

\section{References}

Adamczyk, B., Adamczyk, S., Kukkola, M., Tamminen, P., Smolander, A., 2015: Logging residue harvest may decrease enzymatic activity of boreal forest soils. Soil Biology and Biochemistry, 82:74-80.

Adamczyk, B., Ahvenainen, A., Sietiö, O. M., Kanerva, S., Kieloaho, A. J., Smolander, A. et al., 2016: The contribution of ericoid plants to soil nitrogen chemistry and organic matter decomposition in boreal forest soil. Soil Biology and Biochemistry, 103:394-404.

Achat, D. L., Deleuze, C., Landmann, G., Pousse, N., Ranger, J., Augusto, L., 2015: Quantifying consequences of removing harvesting residues on forest soils and tree growth - A meta-analysis. Forest Ecology and Management, 348:124-141.

Bardgett, R., 2005: The Biology of Soil. Oxford University Press, 255 p.

Benefield, C. B., Howard, P. J., Howard, D. M., 1977:The estimation of dehydrogenase activity in soil. Soil Biology and Biochemistry, 6:67-70.

Blońska, E., 2010: Enzyme activity in forest peat soils. Folia Forestalia Polonica, Series A, 52:20-25.

Das, S. K., Varma, A., 2011: Role of Enzymes in Maintaining Soil Health. In: Shukla, G., Varma, A. (eds.): Soil Enzymology, p. 25-42.

Dilly, O., 2010: Microbial Energetics in Soils. In: Buscot, F., Varma, A. (eds.): Microorganisms in Soils: Roles in Genesis and Functions, Berlin/Heidelberg, SpringerVerlag, p. 123-138.
Fernández-Calviño, D., Soler-Rovira, P., Polo, A., DíazRaviña, M., Arias-Estévez, M., Plaza, C., 2010: Enzyme activities in vineyard soils long-term treated with copper-based fungicides. Soil Biology and Biochemistry, 42:2119-2127.

Fontaine, S., Mariotti, A., Abbadie, L., 2003: The priming effect of organic matter: A question of microbial competition? Soil Biology and Biochemistry, 35:837-843.

Geng, Y., Dighton, J., Gray, D., 2012: The effects of thinning and soil disturbance on enzyme activities under pitch pine soil in New Jersey Pinelands. Applied Soil Ecology, 62:1-7.

Hanajík, P., 2015: Microbial PLFA, Organic Carbon Fractions and Microbial Biomass in Soils under Different Windthrow Management in Biospheric Reservation of the Tatras. ATINER's Conference Paper Series No: ERT2015-1722,p.1-12, Athens, Athens Institute for Education and Research ATINER.

Hanajík, P., Fritze, H., 2009: Effects of forest management on soil properties at windthrow area in Tatra National Park (TANAP). Acta Environmentalica Universitatis Comenianae (Bratislava), 17:36-46.

Hanajík, P., Šimonovičová, A., Vykouková, I., 2016: Vybrané pôdno-ekologické charakteristiky na kalamitnom území v TANAP-e (2005-2016). Ostrava, Vysoká škola báňská - Technická univerzita Ostrava, $99 \mathrm{p}$.

Hazlett, P. W., Gordon, A. M., Voroney, R. P., Sibley, P. K., 2007: Impact of harvesting and logging slash on nitrogen and carbon dynamics in soils from upland spruce forests in northeastern Ontario. Soil Biology and Biochemistry, 39:43-57.

Chen, Z. J., Tian, Y. H., Zhang, Y., Song, B. R., Li, H. C., Chen, Z. H., 2016: Effects of root organic exudates on rhizosphere microbes and nutrient removal in the constructed wetlands. Ecological Engineering, 92:243-250. 
Januszek, K., Długa, J., Socha, J., 2015: Dehydrogenase activity of forest soils depends on the assay used. International Agrophysics, 29:47-59.

Koreň, M., 2005: Vetrová kalamita 19. novembra 2004 - Nové pohlady a konsekvencie. Výskumná stanica a Múzeum TANAP-u, ŠL TANAP-u.

Von Mersi, W., Schinner, F., 1991: An improved and accurate method for determining the dehydrogenase activity of soils with iodonitrotetrazolium chloride. Biology and Fertility of Soils, 11:216-220.

Özkan, U., Gökbulak, F., 2017: Effect of vegetation change from forest to herbaceous vegetation cover on soil moisture and temperature regimes and soil water chemistry. CATENA, 149:158-166.

Paul, E. A., 2007: Soil Microbiology, Ecology, and Biochemistry in Perspective. Soil Microbiology, Ecology and Biochemistry. Elsevier Inc. USA, 2004:3-24.

Pett-Ridge, J., Firestone, M. K., 2005: Redox Fluctuation Structures Microbial Communities in a Wet Tropical Soil. Applied and Environmental Microbiology, 71:6998-7007.

Quilchano, C., Marañón, T., 2002: Dehydrogenase activity in Mediterranean forest soils. Biology and Fertility of Soils, 35:102-107.

Salazar, S., Sánchez, L. E., Alvarez, J., Valverde, A., Galindo, P., Igual, J. M. et al., 2011: Correlation among soil enzyme activities under different forest system management practices. Ecological Engineering, 37:1123-1131.

Shaw, L. J., Burns, R. G., 2006: Enzyme Activity Profiles and Soil Quality. In: Bloem, J. et al. (ed.): Microbiological methods for assessing soil quality, p. 158-183.
Song, Y., Deng, S. P., Acosta-Martínez, V., Katsalirou, E., 2008: Characterization of redox-related soil microbial communities along a river floodplain continuum by fatty acid methyl ester (FAME) and 16S rRNA genes. Applied Soil Ecology, 40:499-509.

Trevors, J. T., 1984a: Effect of substrate concentration, inorganic nitrogen, $\mathrm{O} 2$ concentration, temperature and $\mathrm{pH}$ on dehydrogenase activity in soil. Plant and Soil, 77:285-293.

Trevors, J. T., 1984b: Dehydrogenase activity in soil: a comparison between the INT and TTC assay. Soil Biology and Biochemistry, 16:673-674.

Vance, E. D., Brookes, P. C., Jenkinson, D. S., 1987: An extraction method for measuring soil microbial biomass C. Soil Biology and Biochemistry, 19:703-707.

VonMersi, W., Schinner, F., 1991: An improved and accurate method for determining the dehydrogenase activity of soils with iodonitrotetrazolium chloride. Biology and Fertility of Soils, 11:216-220.

Waldron, K., Ruel, J. C., Gauthier, S., 2013: Forest structural attributes after windthrow and consequences of salvage logging. Forest Ecology and Management, 289: 28-37.

Wolinska, A., Stepniewska, Z., 2012: Dehydrogenase Activity in the Soil Environment. In: Canuto, R. A. (ed.): Dehydrogenases, p. 183-210.

Xu, J., Xue, L., Su, Z., 2016: Impacts of Forest Gaps on Soil Properties After a Severe Ice Storm in a Cunninghamia lanceolata Stand. Pedosphere, 26:408-416.

Yang, Y., Geng, Y., Zhou, H., Zhao, G., Wang, L., 2017: Effects of gaps in the forest canopy on soil microbial communities and enzyme activity in a Chinese pine forest. Pedobiologia, 61:51-60. 